\title{
JURNAL PSIKODIDAKTIKA
}

\section{UPAYA MENINGKATKAN PEMAHAMAN SELF MANAGEMENTMELALUI LAYANAN BIMBINGAN KELOMPOK DENGAN TEKNIK ROLE PLAYING PADA SISWA KELAS X IPA SMA NEGERI 7 KOTA BENGKULU}

\author{
Yayuk Okta Pernamasari ${ }^{1}$, Syamsuddin ${ }^{2}$, Heni Sulusyawati ${ }^{3}$ \\ ${ }^{12,3}$ Prodi Bimbingan dan Konseling Universitas Prof. Dr. Hazairin,S.H
}

e-mail:yayuk@gmail.com ${ }^{1}$ Syamsuddin10081956@gmail.com ${ }^{2}$ henisulusyawati9@gmail.com³

\begin{abstract}
This study aims: (1) to determine the level of self management in student learning before getting group guidance services, (2) to know the level of self management in student learning after getting group guidance services, and (3) to find out group guidance services can improve self management in student learning before and after being given group guidance services. This research method is action research in counseling and guidance services (PTBK). The data collection techniques in this study are using questionnaires, observation, and documentation. This study uses descriptive quantitative data analysis with a percentage formula. The results showed that: (1) The level of self management in student learning before being given group guidance with role playing techniques was in the low category with an average score of 68, (2) Level of self management in student learning after getting group guidance services with role techniques playing is in the high category with an average score of 109, (3) the level of self management in student learning experiences a good increase, before being given group guidance services the level of self management of students is low with an average score of 68 and after being given group guidance services has increased with an average score of 109. This shows that there was a significant increase in the low category to be high with a score of 41 difference.
\end{abstract}

\section{Keywords: Self Management, Guidance Groups, Role Playing Techniques}

\begin{abstract}
ABSTRAK
Penelitian ini bertujuan: (1) untuk mengetahui tingkat self management dalam belajar siswa sebelum mendapatkan layanan bimbingan kelompok, (2) mengetahui tingkat self management dalam belajar siswa sesudah mendapatkan layanan bimbingan kelompok, dan (3) untuk mengetahui layanan bimbingan kelompok dapat meningkatkan self management dalam belajar siswa sebelum dan sesudah diberi layanan bimbingan kelompok.Metode penelitian ini adalah penelitian tindakan dalam layanan bimbingan dan konseling (PTBK). Adapun teknik pengumpulan data dalam penelitian ini yaitu menggunakan angket, observasi, dan dokumentasi. Penelitian ini menggunakan analisis data deskriptif kuantitatif dengan rumus persentase.Hasil penelitian menunjukkan bahwa: (1) Tingkat self management dalam belajar siswa sebelum diberikan bimbingan kelompok dengan teknik role playing berada pada kategori rendah dengan skor rata-rata 68, (2) Tingkat self managementdalam belajar siswa sesudah mendapatkan layanan bimbingan kelompok dengan teknik role playing berada pada kategori tinggi dengan rata-rata skor 109, (3) Tingkat self management dalam belajar siswa mengalami peningkatan yang baik, sebelum diberikan layanan bimbingan kelompok tingkat self management siswa rendah dengan skor rata-rata 68 dan sesudah diberikan layanan bimbingan kelompok mengalami peningkatan dengan skor rata-rata 109. Hal tersebut menunjukkan bahwa terjadi peningkatan yang signifikan dengan kategori rendah menjadi tinggi dengan selisish skor 41
\end{abstract}

Keywords: Self Management, Bimbingan Kelompok, Teknik Role Playing 


\section{PENDAHULUAN}

Setiap siswa seyogyanya mengetahui tugas utamanya di sekolah yaitu belajar, melalui kegiatan belajar diharapkan siswa dapat berkembang secara optimal sesuai dengan tahap perkembangan dirinya. Untuk mewujudkan kegiatan belajar yang baik, tentu setiap siswa harus memiliki self management yang baik. Seorang siswa mesti dapat mengatur dan mengelolah diri dengan baik terutama dalam hal belajar.

Self managementyaitu perubahanprilaku maupun kebiasaan siswa atau klien dalam bentuk latihan pemantauan diri, pengendalian, rangsangan serta pemberian penghargaan pada diri sendiri tanpa paksaan dari orang lain Komalasari, (dalam Fajriani, 2016: 1). Yang bertujuan agar konseli (siswa) dapat mengatur, memantau dan mengevaluasi dirinya sendiri untuk mendapatkan perubahan kebiasaan yang dikehendaki, dengan kata lain self management dalam belajar merupakan kemampuan individu dalam mengelola potensi diri dan potensi lingkungan untuk mengatur perilaku dalam belajar.

Berdasarkan hasil observasi di temukan bahwa siswa kurang berkeinginan untuk membaca, melainkan siswa lebih suka main HP, dan kecenderungan siswa tidak suka bergaul dengan teman-temannya. Siswa lebih suka menyendiri, ketika di dlam kelas siswa lebih banyak pasif di banding yang aktif. Hal ini menunjukkan bahwa self management siswa dalam belajar kurang dan mengakibatkan prestasi siswa menjadi menurun.

Permasalahan self management siswa dalam belajar di atas tidak hanya menjadi tanggungjawab guru bidang studi saja melainkan juga menjadi tanggung jawab guru pembimbing di sekolah melalui berbagai jenis layanan bimbingan dan konseling guru BK dapat membantu siswa siswi untuk memiliki self managemnt yang baik dlam belajar. Salah satunya melalui layanan bimbingan kelompok. Bimbingan kelompok dapat mengupayakan adanya perubahan sikap dan prilaku siswa. (Winkel, 2014:543).

Dalam melaksankan bimbingan kelompok memerlukan suatu teknik. Penelitian ini menggunakan teknik role playing. Menurut Hisyam (2011: 98) role playing yaitu aktivitas pembelajaran yang telah dirancang guna mencapai tujuan dalam pendidikan yang lebih spesifik. Melalui teknik role playing siswa diajak untuk belajar memecahkan masalah pribadi, dengan bantuan kelompok sosial yang anggotanya temanteman sendiri. Teknik ini berupaya membantu individu agar memiliki self management dalam belajar yang baik.

Role playing merupakan sebuah permainan yang memberikan kesempatan kepada para pemeran untuk memerankan karakteristik pemain seperti mereka lakukan sehari-hari dan berkolaborasi dengan pemeran yang lain untuk membentuk sebuah cerita bersama sesuai dengan tema yang telah ditentukan sebelumnya.

Berdasarkan hasil penelitian terdahulu yang dilakukan oleh anik Supriyati (2016). Hasil penelitian menunjukkan bahwa terjadi peningkatan Self Management dalam belajar siswa sebesar $81,12 \%$. Self Management dalam belajar siswa meningkat setelah diberi layanan bimbingan konseling. Selanjutnya hasil penelitian Fajriani (2016) Menunjukkan bahwa salah satu upaya untuk meningkatkan Kedisiplinan Belajar Siswa yaitu melalui teknik Self Management. Relevan dengan penelitian ini karena dalam penelitian ini adalah metode penelitian yang digunakan serta yang menjadi perbedaan dari penelitian ini adalah teknik yang digunakan.

Berdasarkan beberapa penjelasan di atas, maka peneliti ingin mengadakan penelitian dengan judul "Upaya Meningkatkan Self Management dalam Belajar melalui Layanan Bimbingan 
Yayuk Okta Pernamasari ${ }^{1}$, Syamsuddin ${ }^{2}$, Heni Sulusyawati ${ }^{3}$ ISSN: 2615-3297 (Online) \& 2548-6500 (Print)

Kelompok dengan Teknik Role Playing pada Siswa Kelas X IPA SMA Negeri 7 Kota Bengkulu.

\section{METODE}

Jenis penelitian ini adalah penelitian kuantitatif menggunakan metode penelitian tindakan dalam layanan bimbingan dan konseling (PTBK). Metode penelitian tindakan adalah salah satu strategi pemecahan masalah yang memanfaatkan tindakan nyata dan proses pengembangan kemampuan dalam mendeteksi dan memecahkan masalah. Setiap siklus dalam penelitian ini mencakup empat komponen, yaitu perencanaan, pelaksanaan, tindakan, observasi dan refleksi. Keempat komponen yang berupa untaian tersebut dipandang sebagai satu siklus Hidayat 2012:156). Penelitian ini dilakukan di SMA Negeri 7 Kota Bengkulu. Adapun Teknik pengambilan sampel penelitian ini menggunakan teknik sampling purposive yaitu teknik penentuan sampel dengan pertimbangan tertentu Sugiyono, (209:124).Teknik pengumpulan data dalam penelitian ini menggunakan teknik observasi, angket, dan dokumentasi. Analisis data dilakukan secara deskriptif kuantitatif menngunakan rumus persentase Sudjana, (2005: 47).

\section{HASIL PENELITIAN}

\section{Gambaran Self Management dalam Belajar} Siswa Sebelum Mendapatkan Layanan

Subjek penelitian tindakan Bimbingan dan Konseling (PTBK) adalah siswa kelas $\mathrm{X}$ berdasarkan hasil analisis angket rendahnya self management siswa yang dilakukan oleh peneliti. Hal tersebut dikarenakan siswa kelas X IPA 2 SMA Negeri 7 Kota Bengkulu memiliki kriteria-kriteria yang sesuai untuk dijadikan subjek PenelitianTindakan Bimbingan dan Konseling (PTBK).
Adapun krikteria-krikteria yang ada pada siswa kelas X IPA 2 tersebut yaitu:

a. Self management siswa masih dalam kategori rendah.

b. Siswa kelas X IPA yang masih rendah self management masih dipengaruhi oleh faktor teman sebaya yang belum bisa mengelolah dirinya dengan baiak misalnya mengatur waktu belajar dengan baik, pengelolaan pikiran, pengaturan tenaga, pengaturan waktu, pengaturan tempat, watak kepribadian, pengendalian diri, pengembangan diri, dan lain.

Berdasarkan hasil penelitian di peroleh hasil pengukuran yang dilakukan sebelum pelaksanaan layanan Bimbingan Kelompok dengan Teknik Role Playing sebagai berikut:

Tabel 1. Hasil Perolehan Angket Self Management Siswa Sebelum Pelaksanaan Layanan Bimbingan Kelompok

\begin{tabular}{|c|c|c|c|}
\hline No & $\begin{array}{c}\text { Nama } \\
\text { (Inisial) }\end{array}$ & Skor & Kategori \\
\hline 1. & AA & 127 & Sangat Tinggi \\
\hline 2. & AKA & 122 & Tinggi \\
\hline 3. & AM & 72 & Rendah \\
\hline 4. & AJ & 94 & Sedang \\
\hline 5. & AV & 130 & Sangat Tinggi \\
\hline 6. & DDS & 62 & Rendah \\
\hline 7. & DPU & 99 & Sedang \\
\hline 8. & ESB & 64 & Rendah \\
\hline 9. & ERA & 135 & Sangat Tinggi \\
\hline 10. & FS & 70 & Rendah \\
\hline 11. & FR & 98 & Sedang \\
\hline 12. & HAS & 68 & Rendah \\
\hline 13. & IAD & 112 & Tinggi \\
\hline 14. & IKE & 65 & Rendah \\
\hline 15. & KAR & 87 & Sedang \\
\hline 16. & KR & 93 & Sedang \\
\hline 17. & LPN & 73 & Rendah \\
\hline 18. & LHR & 119 & Tinggi \\
\hline 19. & MR & 138 & Sangat Tinggi \\
\hline 20. & MA & 59 & Rendah \\
\hline 21. & WA & 108 & Tinggi \\
\hline 22. & DF & 64 & Rendah \\
\hline 23. & GH & 48 & Sangat Rendah \\
\hline 24. & JT & 107 & Tinggi \\
\hline 25. & SD & 99 & Sedang \\
\hline 26. & ER & 77 & Sedang \\
\hline & & & \\
\hline
\end{tabular}




\begin{tabular}{|c|c|c|c|}
\hline 27. & RE & 121 & Tinggi \\
\hline 28. & AA & 74 & Sedang \\
\hline 29. & MPZ & 60 & Sedang \\
\hline 30. & LPN & 74 & Sedang \\
\hline
\end{tabular}

Berdasarkan tabel di atas maka dapat dilihat adanya variasi hasil angket yang telah dibagikan kepada siswa kelas X IPA 2 yaitu terdapat siswa yang memiliki self management dalam belajar yang sangat tinggi, tinggi, sedang, rendah, dan sangat rendah, lebih jelas akan dipaparkan dalam tabel di bawah ini.

Tabel 2. Self Management dalam Belajar Siswa Sebelum Pelaksanaan Layanan Bimbingan Kelompok

\begin{tabular}{|c|c|c|c|}
\hline No & $\begin{array}{c}\text { Nama } \\
\text { (Inisial) }\end{array}$ & Skor & Kategori \\
\hline 1. & DP & 68 & Rendah \\
\hline 2. & PGR & 64 & Rendah \\
\hline 3. & MPZ & 59 & Rendah \\
\hline 4. & ESB & 87 & Rendah \\
\hline 5. & LPN & 69 & Rendah \\
\hline 6. & NDA & 68 & Rendah \\
\hline 7. & HASL & 70 & Rendah \\
\hline 8. & RA & 64 & Rendah \\
\hline 9. & $\mathrm{AJ}$ & 62 & Rendah \\
\hline 10. & AA & 72 & Rendah \\
\hline \multicolumn{2}{|c|}{ Jumlah } & 683 & \\
\hline \multicolumn{2}{|c|}{ Rata-rata } & 68.3 & Rendah \\
\hline
\end{tabular}

Berdasarkan tabel di atas, dapat diketahui bahwa 9 siswa tergolong kategori rendah dan 1 siswa tergolong kategori sedang dengan jumlah 683 dan rata-rata 68.3.

Tabel 3. Hasil Persentase Self Management dalam Belajar Siswa Sebelum Pelaksanaan Layanan

\begin{tabular}{|c|c|c|c|c|}
\hline No & $\begin{array}{c}\text { Interval } \\
\text { Persentase }\end{array}$ & Frekuensi & $\%$ & Kriteria \\
\hline 1. & $>126$ & - & - & - \\
\hline 2. & $125-101$ & - & - & - \\
\hline 3. & $100-76$ & 1 & 10 & Sedang \\
\hline 4. & $75-51$ & 9 & 90 & Rendah \\
\hline 5. & $>50$ & - & - & \\
\hline \multicolumn{2}{|c|}{ Jumlah } & 10 & 100 & \\
\hline
\end{tabular}

Berdasarkan tabel persentase hasil perhitungan self management di atas, dapat dipahami bahwa self management siswa dalam belajar masih tergolong rendah. Analisis persentase kondisi awal sebelum diperoleh yaitu 1 siswa yang tergolong kategori sedang dengan persentase $10 \%, 9$ siswa tergolong kategori rendah dengan persentase capaian $90 \%$.

\section{Gambaran Self Managementdalam Belajar} Siswa setelah mendapatkan Layanan

Berdasarkan hasil penelitian kondisi awal yang menunjukkan bahwa self management siswa rendah berjumlah 10 orang siswa, maka peneliti bersama kolaborator memberikan tindakan kepada siswa yang memiliki self managementrendah berupa layanan bimbingan kelompok dengan teknik role playing. Pemberian tindakan diberikan sebanyak tiga siklus terhadap siswa kelas $\mathrm{X}$ IPA yang berjumlah 10 orang siswa.

Adapun yang menjadi teknik pelaksanaan layanan bimbingan kelompok yaitu teknik role playing tiap siklus terdiri dari perencanaan (planning), tindakan (Action), pengamatan (Observation), refleksi (Reflection). Untuk mengetahui pelaksanaan layanan dan hasil dari layanan bimbingan kelompok teknik role playing pada self management siswa digunakan alat bantu berupa instrument skala self management siswa dan observasi. Siklus dua yang dapat dilihat pada tabel berikut:

Tabel 4. Self Management Siswa Pelaksanaan Layanan Bimbingan Kelompok dengan Teknik Role PlayingSiklus I

\begin{tabular}{|c|c|c|c|}
\hline No & Nama (Inisial) & Skor & Kategori \\
\hline 1. & DP & 79 & Sedang \\
\hline 2. & PGR & 69 & Rendah \\
\hline 3. & MPZ & 60 & Rendah \\
\hline 4. & ESB & 89 & Sedang \\
\hline 5. & LPN & 70 & Rendah \\
\hline 6 & NDA & 78 & Sedang \\
\hline 7. & HASL & 81 & Sedang \\
\hline 8. & RA & 84 & Sedang \\
\hline 9. & $\mathrm{AJ}$ & 80 & Sedang \\
\hline 10. & $\mathrm{AA}$ & 84 & Sedang \\
\hline \multicolumn{2}{|r|}{ Jumlah } & 774 & \\
\hline \multicolumn{2}{|r|}{ Rata-rata } & 77,4 & Sedang \\
\hline
\end{tabular}


Berdasarkan hasil angket yang telah dibagikan dengan siswa sebelum pelaksanaan layanan bimbingan kelompok dapat diketahui bahwa siswa yang termasuk kategori sedang 7 siswa dan 3 siswa masuk dalam kategori rendah dengan jumlah keseluruhan 774 rata-rata yang di peroleh 77,4.

Tabel 5. Hasil Persentase Self Management Siswa pada Responden setelah mendapatkan Layanan Bimbingan Kelompok

\begin{tabular}{|c|c|c|c|c|}
\hline No & $\begin{array}{c}\text { Interval } \\
\text { Persentase }\end{array}$ & Frekuensi & $\mathbf{\%}$ & Kriteria \\
\hline 1. & $>126$ & - & - & - \\
\hline 2. & $125-101$ & - & - & - \\
\hline 3. & $100-76$ & 8 & 80 & Sedang \\
\hline 4. & $75-51$ & 2 & 20 & Rendah \\
\hline 5. & $>50$ & - & - & - \\
\hline & Jumlah & 10 & 100 & \\
\hline
\end{tabular}

Tabel di atas mengemukakan bahwa self management siswa setelah diberikan tindakan pada siklus 1 mengalami peningkatan dengan kriteria sedang. Berdasarkan persentase siklus 1 tersebut maka diperoleh 8 siswa berada pada kategori sedang dengan tingkat persentase capaian $80 \%$. Dan 2 orang siswa yang berada pada kategori rendah dengan tingkat persentase $20 \%$.

Tabel 6. Self Management Siswa Pelaksanaan Layanan Bimbingan Kelompok dengan Teknik Role Playing SiklusII

\begin{tabular}{|c|c|c|c|}
\hline No & Nama (Inisial) & Skor & Kategori \\
\hline 1. & DP & 88 & Sedang \\
\hline 2. & PGR & 87 & Sedang \\
\hline 3. & MPZ & 80 & Sedang \\
\hline 4. & ESB & 94 & Sedang \\
\hline 5. & LPN & 84 & Sedang \\
\hline 6 & NDA & 102 & Tinggi \\
\hline 7. & HASL & 89 & Sedang \\
\hline 8. & RA & 90 & Sedang \\
\hline 9. & $\mathrm{AJ}$ & 86 & Sedang \\
\hline 10. & AA & 92 & Sedang \\
\hline \multicolumn{2}{|r|}{ Jumlah } & 892 & \\
\hline \multicolumn{2}{|r|}{ Rata-rata } & 89,2 & Sedang \\
\hline
\end{tabular}

Berdasarkan tabel di atas, maka dapat dilihat bahwa terdapat 1 siswa yang tergolong kategori tinggi, dan 9 siswa tergolong dalam kategori sedang dengan jumlah skor 892 dan rata-tara 89,2 .
Tabel 7. Hasil Persentase Self Management Siswa pada Responden setelah mendapatkan Layanan

\begin{tabular}{|c|c|c|c|c|}
\hline No & $\begin{array}{c}\text { Interval } \\
\text { Persentase }\end{array}$ & Frekuensi & $\%$ & Kriteria \\
\hline 1. & $>126$ & - & - & - \\
\hline 2. & $125-101$ & 1 & 10 & Tinggi \\
\hline 3. & $100-76$ & 9 & 90 & Sedang \\
\hline 4. & $75-51$ & - & - & - \\
\hline 5. & $>50$ & - & - & - \\
\hline & Jumlah & 10 & 100 & \\
\hline
\end{tabular}

Berdasarkan tabel di atas, maka dapat diketahui bahwa self management siswa setelah diberikan tindakan berupa layanan bimbingan kelompok dengan teknik role playing pada siklus II mengalami peningkatan. Hal tersebut dapat dilihat dari keseluruhan 10 siswa diperoleh skor rata-rata $89.2 \%$ dengan kriteria sedang. Rata-rata tersebut diperoleh dari 1 siswa yang memiliki persentase $10 \%$ dengan kategori tinggi, dan 9 orang siswa memiliki persentase $90 \%$ dengan kategori tergolong sedang.

Tabel 8. Self Management Siswa Pelaksanaan Layanan Bimbingan Kelompok dengan Teknik Role Playing SiklusIII

\begin{tabular}{|c|c|c|c|}
\hline No & Nama (Inisial) & Skor & Kategori \\
\hline 1. & DP & 114 & Tinggi \\
\hline 2. & PGR & 102 & Tinggi \\
\hline 3. & MPZ & 94 & Sedang \\
\hline 4. & ESB & 112 & Tinggi \\
\hline 5. & LPN & 96 & Sedang \\
\hline 6 & NDA & 116 & Tinggi \\
\hline 7. & HASL & 105 & Tinggi \\
\hline 8. & RA & 123 & Tinggi \\
\hline 9. & AJ & 108 & Tinggi \\
\hline 10. & AA & 120 & Tinggi \\
\hline \multicolumn{2}{|r|}{ Jumlah } & 1.090 & \\
\hline \multicolumn{2}{|r|}{ Rata-rata } & 109 & Tinggi \\
\hline
\end{tabular}

Berdasarkan tabel di atas, maka dapat dilihat bahwa terdapat 8 siswa yang tergolong kategori tinggi dan 2 orang siswa yang tergolong kategori sedang, dengan julah skor 1.090 dan rata-rata 109.

Tabel 9. Hasil Persentase Self Management Siswa setelah mendapatkan Layanan

\begin{tabular}{|c|c|c|c|c|}
\hline No & $\begin{array}{c}\text { Interval } \\
\text { Persentase }\end{array}$ & Frekuensi & $\%$ & Kriteria \\
\hline
\end{tabular}


Yayuk Okta Pernamasari ${ }^{1}$, Syamsuddin ${ }^{2}$, Heni Sulusyawati ${ }^{3}$ ISSN: 2615-3297 (Online) \& 2548-6500 (Print)

\begin{tabular}{|c|c|c|c|c|}
\hline 1. & $>126$ & 0 & 0 & - \\
\hline 2. & $125-101$ & 8 & 80 & Tinggi \\
\hline 3. & $100-76$ & 2 & 20 & Sedang \\
\hline 4. & $75-51$ & 0 & 0 & - \\
\hline 5. & $>50$ & 0 & 0 & - \\
\hline & Jumlah & 10 & 100 & \\
\hline
\end{tabular}

Berdasarkan tabel di atas, dapat diketahui bahwa self management siswa setelah diberikan tindakan berupa layanan bimbingan kelompok dengan teknik role playing pada siklus III mengalami peningkatan. Hal tersebut dapat dilihat dari 10 siswa secara keseluruhan berada pada kriteria tergolong tinggi. Rata-rata tersebut di peroleh dari 8 orang siswa yang memiliki persentase $70 \%$ dengan kategori tinggi, 0 siswa yang memiliki pesentase $0 \%$ dengan kategori rendah, 0 siswa memiliki pesentase 0 dengan kategori sangat rendah, dan 2 orang siswa memiliki persentase $20 \%$ dengan kriteria tergolong sedang.

Pemberian layanan bimbingan kelompok dengan teknik role playing setelah dilakukan perbaikan pada siklus III ternyata dapat meningkatkan sel management siswa dalam belajar kelas X IPA 2 SMA Negeri 7 Kota Bengkulu secara signifikan. Keberhasilan yang diperoleh pada siklus III ini, dapat dilihat pada hasil persentase self management siswa yang mengalami peningkatan dari siklus I dengan ratarata persentase 77\% dengan kategori sedang, pada siklus II persentase 89\% dengan kategori sedang, sedangkan pada siklus III persentase 109 dengan kategori tinggi.

\section{Gambaran Self Management dalam belajar} siswa Setelah Mendapat Layanan

Mengacu pada tujuan penelitian untuk mengetahui gambaranself management pada 10 siswa kelas X IPA SMA Negeri 7 Kota Bengkulu yang kategori rendah setelah mendapat layanan bimbingan kelompok teknik role playing, maka akan dipaparkan mengenai gambaran self management siswa pada kondisi awal sebelum diberikan tindakan layanan, siklus I siklus II dan siklus III dan setelah diberikan tindakan layanan, serta dijelaskan pula bagaimana peningkatan self management siswa dari kategori rendah sampai pada kategori tinggi.Hal tersebut dijelaskan secara rinci pada tabel berikut:

Tabel 10. Hasil Persentase self management siswa pada Responden Kondisi Awal dan Setelah Mendapat Layanan

\begin{tabular}{|c|c|c|c|c|c|c|}
\hline \multirow{2}{*}{ No } & \multirow{2}{*}{ Interval } & \multirow{2}{*}{ Kriteria } & \multicolumn{2}{|c|}{ Kondisi Awal } & \multicolumn{2}{|c|}{ Siklus I } \\
\cline { 4 - 7 } & & & Frek & $\%$ & Frek & $\%$ \\
\hline 1. & $>126$ & ST & 0 & 0 & 0 & 0 \\
\hline 2. & $125-101$ & $\mathrm{~T}$ & 0 & 0 & 0 & 0 \\
\hline 3. & $100-76$ & $\mathrm{~S}$ & 1 & 10 & 7 & 70 \\
\hline 4. & $75-51$ & $\mathrm{R}$ & 9 & 90 & 3 & 30 \\
\hline 5. & $>50$ & SR & 0 & 0 & 0 & 0 \\
\hline \multicolumn{2}{|c|}{ Jumlah } & 10 & 100 & 10 & 100 \\
\hline
\end{tabular}

Keterangan:

$\begin{array}{ll}\text { ST } & \text { : Sangat Tinggi } \\ \text { T } & : \text { Tinggi } \\ \text { S } & \text { : Sedang } \\ \text { R } & \text { : Rendah } \\ \text { SR } & \text { : Sangat Rendah }\end{array}$

Berdasarkan tabel di atas, dapat diketahui bahwa terdiri perubahan persentase self management siswa antara kondisi awal dengan siklus I

Pertama, perubahan hal tersebut terlihat pada kriteria sangat tinggi 0 memiliki persentase $0 \%$.

Kedua, terjadi perubahan hal tersebut terlihat pada kriteria tinggi 8 memiliki persentase $80 \%$.

Ketiga, terjadi perubahan hal tersebut terlihat pada kriteria sedang 2 memiliki persentase $20 \%$.

Keempat, terjadi perubahan hal tersebut terlihat pada kriteria rendah 0 memiliki persentase $0 \%$. 
Kelima terjadi perubahan hal tersebut terlihat pada kriteria sangat rendah 0 memiliki persentase $0 \%$.

Disamping distribusi frekuensi persentase keseluruhan responden pada kondisi awal dan setelah tindakan siklus I di atas, dibawah ini juga terdapat tabel presentase per responden dengan perbedaan presentase setelah tindakan siklus I dan siklus II. Secara lengkap dapat disajikan sebagai berikut:

Tabel 11. Hasil Persentase Kecerdasan Emosional Siswa pada Responden Kondisi Awal dan Setelah Mendapatkan Layanan Bimbingan Kelompok Teknik Role Playing Siklus 1, siklus 2, dan siklus 3

\begin{tabular}{|c|c|c|c|c|c|c|c|c|c|c|}
\hline \multirow[t]{2}{*}{ No } & \multirow[t]{2}{*}{$\begin{array}{c}\text { Interv } \\
\text { al }\end{array}$} & \multirow[t]{2}{*}{ Krik } & \multicolumn{2}{|c|}{$\begin{array}{c}\text { Kondisi } \\
\text { Awal }\end{array}$} & \multicolumn{2}{|c|}{ Siklus 1} & \multicolumn{2}{|c|}{ Siklus II } & \multicolumn{2}{|c|}{ Siklus III } \\
\hline & & & Frek & $\%$ & Frek & $\%$ & Frek & $\%$ & Frek & $\%$ \\
\hline 1. & $>126$ & ST & 0 & 0 & 0 & 0 & 0 & 0 & 0 & 0 \\
\hline 2. & $\begin{array}{c}125- \\
101\end{array}$ & $\mathrm{~T}$ & 0 & 0 & 0 & 0 & 1 & $\begin{array}{l}1 \\
0 \\
\end{array}$ & 8 & $\begin{array}{l}8 \\
0 \\
\end{array}$ \\
\hline 3. & $\begin{array}{c}100- \\
76\end{array}$ & S & 1 & $\begin{array}{l}1 \\
0\end{array}$ & 7 & $\begin{array}{l}7 \\
0\end{array}$ & 9 & $\begin{array}{l}9 \\
0\end{array}$ & 2 & $\begin{array}{l}2 \\
0\end{array}$ \\
\hline 4. & $75-51$ & $\mathrm{R}$ & 9 & $\begin{array}{l}9 \\
0\end{array}$ & 3 & $\begin{array}{l}3 \\
0\end{array}$ & 0 & 0 & 0 & 0 \\
\hline 5. & $>50$ & SR & 0 & 0 & 0 & 0 & 0 & 0 & 0 & 0 \\
\hline & $\begin{array}{c}6 . \\
\text { Jumlah }\end{array}$ & & 10 & $\begin{array}{l}1 \\
0 \\
0\end{array}$ & 10 & $\begin{array}{l}1 \\
0 \\
0\end{array}$ & 10 & $\begin{array}{l}1 \\
0 \\
0\end{array}$ & 10 & $\begin{array}{l}1 \\
0 \\
0\end{array}$ \\
\hline
\end{tabular}

Keterangan:

$\begin{array}{ll}\text { ST } & \text { : Sangat Tinggi } \\ \mathrm{T} & \text { : Tinggi } \\ \mathrm{S} & \text { : Sedang } \\ \mathrm{R} & \text { : Rendah } \\ \mathrm{SR} & \text { : Sangat Rendah }\end{array}$

Berdasarkan tabel di atas dapat diketahui bahwa terjadi perubahan yang signifikan pada persentase kecerdasan emosional siswa antara siklus I,siklus II, dan siklus III.

Pertama, Perubahan tersebut dilihat dari interval kurang dari>126 dengan kategori sangat tinggi memiliki frekuensi sebesar siklus I memiliki frekuensi 0 dengan persentase 0 .

Kedua, terjadi perubahan pada interval kurang dari >125 dengan kategori tinggi yang pada siklus I memiliki frekuensi 0 dengan persentase $0 \%$, setelah dilakukan siklus III mengalami peningkatan frekuensi menjadi 8 dengan pesentase $8 \%$.

Ketiga, pada interval kurang dari $>100$ dengan kriteria sedang, pada siklus I memiliki frekuensi 7 dengan persentase $70 \%$ setelah dilakukan tindakan siklus III terjadi peningkatan dengan berkurangnya frekuensi menjadi 2 dengan persentase $2 \%$.

Keempat, interval kurang dari $>75$ dengan kriteria tinggi pada siklus I memiliki frekuensi dengan persentase $30 \%$, setelah diberikan tindakan siklus III maka mengalami peningkatan dengan berkurangnya kriteria rendah frekuensi 0 dengan persentase $0 \%$.

Kelima, interval kurang dari >50 dengan kriteria sangat rendah kemudian pada siklus I memiliki frekuensi 0 dengan persentase $0 \%$, setelah diberikan tindakan pada siklus III mengalami peningkatan dengan berkurangnya kriteria rendah dengan frekuensi 0 dan persentase $0 \%$

\section{PEMBAHASAN}

1. Tingkat Self Management Sebelum Mendapatkan Layanan Bimbingan

Berdasarkan proses dan hasil pelaksanaan tindakan layanan yang diberikan pada 10 siswa kelas X IPA 2 SMA Negeri 7

Kota Bengkulu yang memiliki self management dengan rata-rata persentase $77 \%$ dengan kategori sedang. Kelas X IPA 2 dipilih sebagai subjek penelitian tindakan berdasarkan hasil penelitian dan analisis kondisi awal pada seluruh siswa kelas X SMA Negeri 7 Kota Bengkulu dengan menggunakan angket perencanaan self management siswa SMA. Menurut Gie (dalam Supriyati, 2013: 02) menyatakan self management berarti mendorong diri sendiri untuk maju, mengatur semua unsur kemampuan pribadi, mengendalikan kemampuan untuk mencapai hal-hal yang baik, dan mengembangkan berbagai segi dari kehidupan pribadi agar lebih sempurna.

Alasan peneliti melakukan penelitian tindakan pada siswa kelas X IPA 2 SMA 
Negeri 7 Kota Bengkulu dikarenakan tingkat self management pada siswa kelas X IPA 2 SMA Negeri 7 Kota Bengkulu memiliki kategori rendah karena masih dibawah ratrata. Rendahnya tingkat self management siswa karena disebabkan fisik dan perhatian terhadap waktu, kondisi sosial, kesehatan, prasaan, kemampuan berpikir dan memotivasi serta mempengaruhi self management siswa adalah latar belakang tingkat kondisi sosial ekonomi, tingkat pendidikan, dan kendala lingkungan sekitar.

2. Tingkat Self Management dalam Belajar Siswa Sesudah Mendapatkan Layanan

Melalui layanan bimbingan kelompok dengan teknikrole playing maka dapat dilihat bahwa hasil siklus II self management siswa mengalami peningkatan. Berdasarkan permasalahan tersebut, diperlukan layanan bimbingan kelompok. Maka peneliti melakukan penelitian tindakan kelas berupa layanan bimbingan kelompok dengan teknik role playing. Pemilihan layanan bimbingan kelompok sebagai tindakan untuk meningkatkan self management siswa..

Selain itu menurut penelitian terdahulu alasan peneliti menggunakan layanan bimbingan kelompok dengan teknik role playing untuk meningkatkan self management siswa karena menurut Goleman, (2009:95) salah satu cara peningkatan self management dalam belajar terbentuk dari adanya sikap positif. Adanya sikap pendorong diri akan mendororng individu agar memiliki tekat yang benar untuk belajar. Kemudian selain pendorong terdapat pula penyususnan diri yang berguna untuk mengatur berbagai sumber daya yang diperlukan untuk mendukung kegiatan belajar individu dengan tujuan untuk mencapai koefisien pada hidupnya. Aspek-aspek self management terdiri pendorong diri, pengendalian diri, penyusunan diri, dan pengembangan diri.

Disamping itu layanan bimbingan kelompok dengan teknik role palying merupakan layanan yang diberikan oleh pembimbing kepada kelompok siswa yang bertujuan membantu siswa yang menghadapi masalah dengan cara membahas permasalahan tersebut dengan saling kerja sama, unsur percaya mempercayai antar anggota sehingga memperoleh manfaat bagi kehidupannya.

Secara keseluruhan hasil persentase self management siswa yang diperoleh dari kondisi awal memiliki kategori rendah. Rendahnya indikator-indikator self management siswa pada kondisi awal dikarenakan siswa belum mendapatkan tindakan berupa layanan bimbingan kelompok dengan teknik role playing yang mempengaruhi self management pada siswa kelas X IPA 2 SMA Negeri 7 Kota Bengkulu. Pemberian tindakan layanan bertujuan untuk memperbaiki proses layanan yang sudah dilakukan oleh Guru BK yang belum maksimal dan untuk meningkatkan serta mengetahui gambaran self management siswa. Teknik pelaksanaan layanan dilakukan dengan tiga siklus yang terdiri dari empat tahapan, yaitu perencanaan, tindakan, pengamatan, refleksi.

\section{Layanan Bimbingan Kelompok dengan} Teknik Role Playing dapat Meningkatkan Self Management

Berdasarkan hasil yang diperoleh mengenai self management sebelum mendapat layanan bimbingan kelompok siklus 1 dengan rata-rata persentase $77 \%$ dengan kategori sedang, dan sesudah mendapat layanan 
bimbingan kelompok siklus II dengan ratarata persentase $89 \%$ dengan kategori sedang, dan pada siklus III mengalami peningkatan sebelum dan sesudah diberi layanan bimbingan kelompok. Analisis persentase siklus I tersebut diperoleh yaitu 6 siswa yang mendapatkan kategori sedang dengan persentase $60 \%, 3$ orang siswa mendapatkan kategori rendah dengan persentase $30 \%$. Ratarata pada siklus II diperoleh dari siswa yang memiliki persentase $10 \%$ dengan kategori sangat tinggi 9 orang siswa dengan persentase 90\% dengan kategori sedang.

Self management siswa setelah diberikan tindakan pada siklus III mengalami peningkatan. Hal tersebut dapat dilihat dari 10 siswa yang mengisi skala Self Management setelah diberikan tindakan layanan bimbingan kelompokteknik role playing secara keseluruhan berada pada kriteria tinggi. Ratarata tersebut diperoleh dari 0 siswa yang memiliki persentase 00\% dengan kategori sangat tinggi, 8 orang siswa yang memiliki persentase $80 \%$ dengan kategori tinggi.

Pemberian layanan bimbingan kelompok setelah dilakukan perbaikan pada siklus III ternyata dapat meningkatkan selfmanagement pada siswa kelas X IPA SMA Negeri 7 Kota Bengkulu secara signifikan. Keberhasilan yang diperoleh pada siklus III ini dari 10 siswa yang self management rendah, dapat terlihat pada hasil persentase self managemen siswa yang mengalami peningkatan dari sebelum diberikan layanan bimbingan kelompok teknik role playing dengan kategori sangat rendah. Namun setelah diberikan bimbingan kelompok teknik role playing hasil persentase self management siswa yang mengalami peningkatan dari siklus I dengan rata-rata persentase $77 \%$ dengan kategori sedang, pada siklus II persentase $89 \%$ dengan kategori sedang. Sedangkan pada siklus III persentase $109 \%$ dengan kriteria tinggi.

Bimbingan kelompok teknik role playing dalam penelitian ini merupakan upaya pemberian bantuan kepada siswa secara kelompok untuk mengambil keputusan yang tepat dan mandiri dalam dinamika kelompok untuk mendapatkan informasi tentang self management siswa. Dalam pelaksanaan bimbingan kelompok terdapat empat tahap yaitu, tahap pembentukan, tahap peralihan, tahap kegiatan, dan tahap pengakhiran.

Menurut prayitno (2004:03)'layanan bimbingan kelompok dapat digunakan untuk mengubah dan mengembangkan sikap dan prilaku yang efektif menjadi lebih efektif". Perubahan yang terjadi yaitu perubahan self management siswa alami setelah memahami bahwa self management baik dalam kehidupan mereka.

Layanan bimbingan kelompok teknik role playing memberikan kontribusi dalam meningkatkan self management oleh siswa. Dalam pelaksanaan layanan bimbingan kelompok teknik role playing didalamnya berisi materi tentang bagaimana agar siswa sebagai anggota kelompok akan sama-sama menciptakan dinamika kelompok melatih diri dalam mengemukakan pendapatnya, membahas topik-topik yang ada, siswa dapat saling bertukar informasi, memberi saran dan pengalaman mereka untuk bisa bersikap atertif di dalam kelompok tersebut.

\section{KESIMPULAN}

Berdasarkan hasil penelitian dijelaskan sebelumnya, dapat ditarik kesimpulan antara lain: 
1. Sebelum diberikan layanan bimbingan kelompok tingkat Self management dalam belajar siswa tergolong rendah dengan skor rata-rata 68

2. Setelah diberikan layanan bimbingan kelompok tingkat self managementdalam belajar siswa berada pada kategori tinggi, hal ini ditunjukkan dengan rata-rata skor 109.

3. Layanan bimbingan kelompok menggunakan teknik role playing dapat meningkatkan self management dalam belajar siswa. Hal ini ditunjukkan oleh perolehan skor sebelumnya 68 dan setelah diberikan layanan meningkat menjadi 109.

\section{SARAN}

Berdasarkan hasil penelitian yang diperoleh, maka dapat di kemukakan beberapa saran yaitu:

1. Bagi kepala sekolah diharapkan agar dapat menyediakan sarana dan fasilitas yang mendukung kegiatan layanan bimbingan dan konseling terutama layanan bimbingan kelompok.

2. Bagi Guru Bimbingan dan Konseling (BK) Diharapkan dapat menggunakan dan mengembangkan layanan konseling kelompok menggunakan teknik role playinguntuk meningkatkan pemahaman self management siswa.

3. Bagi Peneliti Selanjutnya

Perlu dilakukan penelitian yang sejenis, dengan latar belakang yang berbeda, misalnya penelitian kualitatif agar dapat memberikan perbandingan dari hasil penelitian saat ini, dan dapat memperdalam, memperjelas, serta dapat memberikan temuan terbaru, terkait dengan meningkatkan pemahaman self management. Sehingga hasil yang ditemukan dapat digeneralisasikan dalam ruang lingkup yang lebih luas.

\section{DAFTAR RUJUKAN}

Fajrini. 2016. Self-Management untuk Meningkatan Kedisiplinan Belajar Siswa: Studi Kasuss Di SMA Negeri 5 Banda Ance. Skripi: Tidak diterbitkan

Hamzah. 2018. Orientasi Baru dalam Psikologi Pembelajaran. Yogyakarta: Media Abadi. Hermansyah. 2012. Korelasi Pengaruh Faktor Efikasi Diri dan Manajemen Diri terhadap Motivasi Berprestasi pada Mahasiswa Pendidikan Kimia Universitas Bengkulu. Jurnal UNIB, 12/6.

Hidayat. 2012. Edisi Revisi prosedur Penelitian Suatu Pendekatan Praktek. Jakarta: Rineka Cipta.

Hisyam. 2011. Strategi Pembelajaran Aktif. Yogyakarta: Media Abadi.

Komalasari, Gantina dan Eka Wahyuni. 2011. Teori dan Teknik Konseling. Jakarta: Pt Indeks.

Prayitno. 2004. Layanan Bimbingan Kelompok. Universitas Negeri Padang.

Sudjana, Nana. 2002. Penilaian Hasil Proses Belajar. Remaja Rosdakarya. Bandung.

Sukardi, Dewa Ketut. 2005. Pengantar Pelaksanaan Program Bimbingan dan Konseling. Jakarta: Rineka Cipta.

Sugiyono. 2010. Metode Penelitian Pendidikan Pendekatan Kuantitatif, Kualitatif, dan $R \& D$. Bandung: CV. Alfabeta.

Supriyati. 2013. Upaya Meningkatkan Self Management dalam Belajar Melalui Layanan Bimbingan Konseling pada Siswa Kelas VIIID Di SMPN I Jakenan Pati. Jurnal, Pendidikan Penabur, No. 07. Tahun V. Desember 2006. Halaman 64-71 
Yayuk Okta Pernamasari ${ }^{1}$, Syamsuddin ${ }^{2}$, Heni Sulusyawati ${ }^{3}$ ISSN: 2615-3297 (Online) \& 2548-6500 (Print)

Tohirin. 2007. Bimbingan dan Konseling di Sekolah dan Madrasah (Berbasis Integrasi. Jakarta: Raja Grafindo Persada.

Winkel. WS dan MM Sri Hastuti. 2004. Bimbingan dan Konseling di Institusi Pendidikan. Yogyakarta: Media Abadi.
Wiriatmaja. 2006. Statistik Pendidikan. Bandung: CV Pusaka Satia. 